Tori, 29: 91-94, 1980.

\title{
On the Calls of the Collared Scops Owl Otus bakkamoena in Japan
}

\author{
Hiroyoshi Higuchi and Hiroshi Momose* \\ Laboratory of Forest Zoology, Faculty of Agriculture, \\ University of Tokyo, Bunkyo-ku, Tokyo 113; \\ Biology Department, International Christian \\ University, Mitaka, Tokyo 181
}

\section{日本にすむオオコノハズクの鳴き声について \\ 樋口広芳・百瀬 浩* \\ 東京大学農学部森林動物学教室 国際キリスト教大学生物学教室}

Koвayashi (1954) and JAPB (1966) describe the call of the Collared Scops Owl Otus bakkamoena as "woz, woz" or "hoz, hoz, hoz". Kryosu (1965), on the other hand, mentions that this species calls "pou pou, pou pou" in May and June. Although these authors implied that the calls they described are typical of the species, we have not observed Collared Scops Owls uttering such sounds. Their call that we have heard are quite different from those that have been described in books of Japanese birds.

We have observed Collared Scops Owls on Miyake-jima, Izu Islands since 1978 and recorded the voice throughout the year. In this short paper, our observations on the calls and the seasonal fluctuations in calling frequency are reported.

Fig. 1 shows the sonagram of the call uttered most commonly by Collared Scops Owls on Miyake-jima. It sounds like "koo" or "kwee" and is one syllable voice uttered at intervals of a few seconds. This call seems to be used in territorial defence and in communication between the male and the female of a pair. Incubating females often utter the call in the nest. Similar calls were also frequently heard before dawn at Lake Shoji on Mt. Fuji on May 4, 1978, although no tape recordings were made for detailed comparison. This kind of call is apparently the one most commonly uttered by the Japanese Collared Scops Owl.

Marshall (1978) has reported the calls of south-east Asian populations of the Collared Scops Owl. According to his phonodisc and sonagrams, the regular calls of Thailand, Singapore and Sumatra populations are not dissimilar to those of Japanese birds. Their calls are also one-syllable and

\footnotetext{
* Present address: Shiraitodai 1-71-4, Fuchu-shi, Tokyo 183. 現住所: $₹ 183$ 東京都府中
} 市白糸台 1-71-4. 


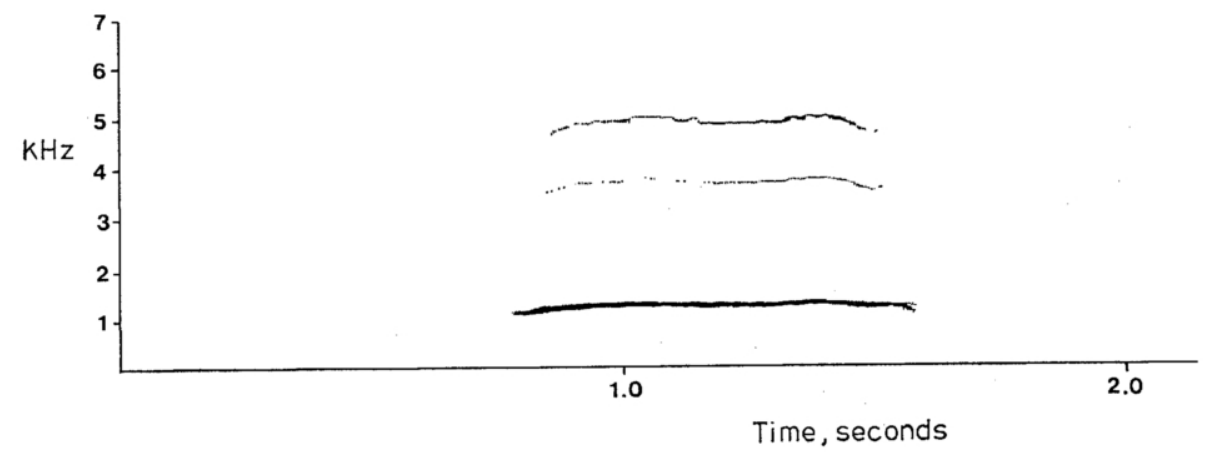

Fig. 1. Sonagram of the regular call ("koo" or "kwee" call) of Otus bakkamoena on Miyake-jima, Izu Islands.

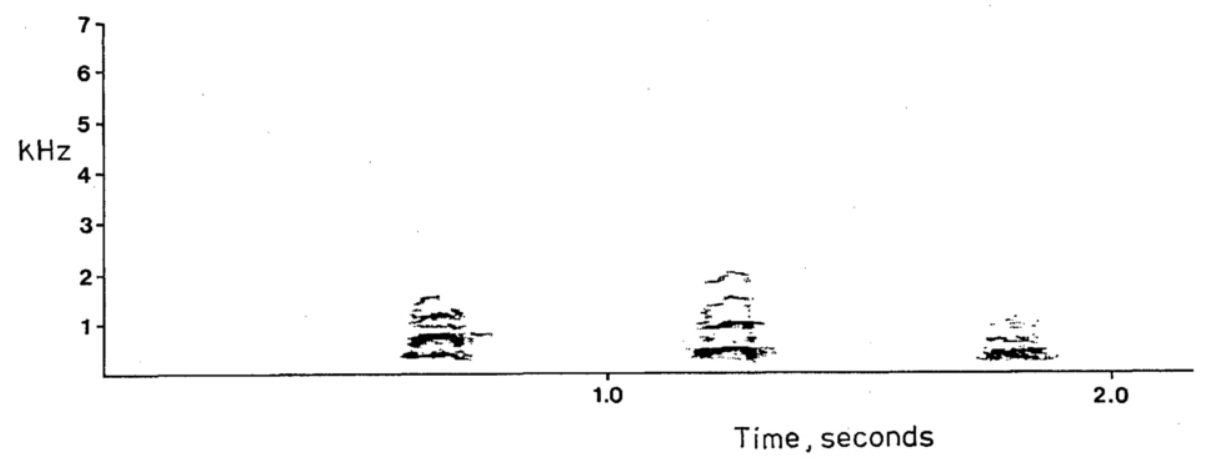

Fig. 2. Sonagram of the 'dog call' of male Otus bakkamoena on Miyake-jima, Izu Islands.

sound like "boo." The populations of Thailand and Malay Peninsula have notes inflected downward, whereas the call is a rising in Sumatora population. The call of Singapore population is even with no inflection, having apparent similarity to the call of the Japanese population. MARSHaLl (1978) says that these regular calls are the territorial call of males, whereas the calls of females are higher, quavering, whining, muffled "wheoo" which is always inflected downward. However, we were unable to distinguish clearly the regular calls of males and females in Japanese birds.

Besides the calls mentioned above, the Collared Scops Owls of Miyakejima have other calls like voices of the dog and those of the cat. The 'dog call' is shown in Fig. 2. It is a loud call which sounds like "won, won", and was often uttered by the male approaching the nest in which the female sat on her eggs or young. We have not heard the dog call outside the breeding season. On the other hand, the 'cat call', which sounds like "myau, myau", was also heard in winter. It is not known in what conditions the cat call is uttered. Among other sounds, we have sometimes heard a 'cry' like "Gyau" or "Gyu" in the breeding season. This call is similar to a dog's cry which is produced when its foot is stamped. The function of 


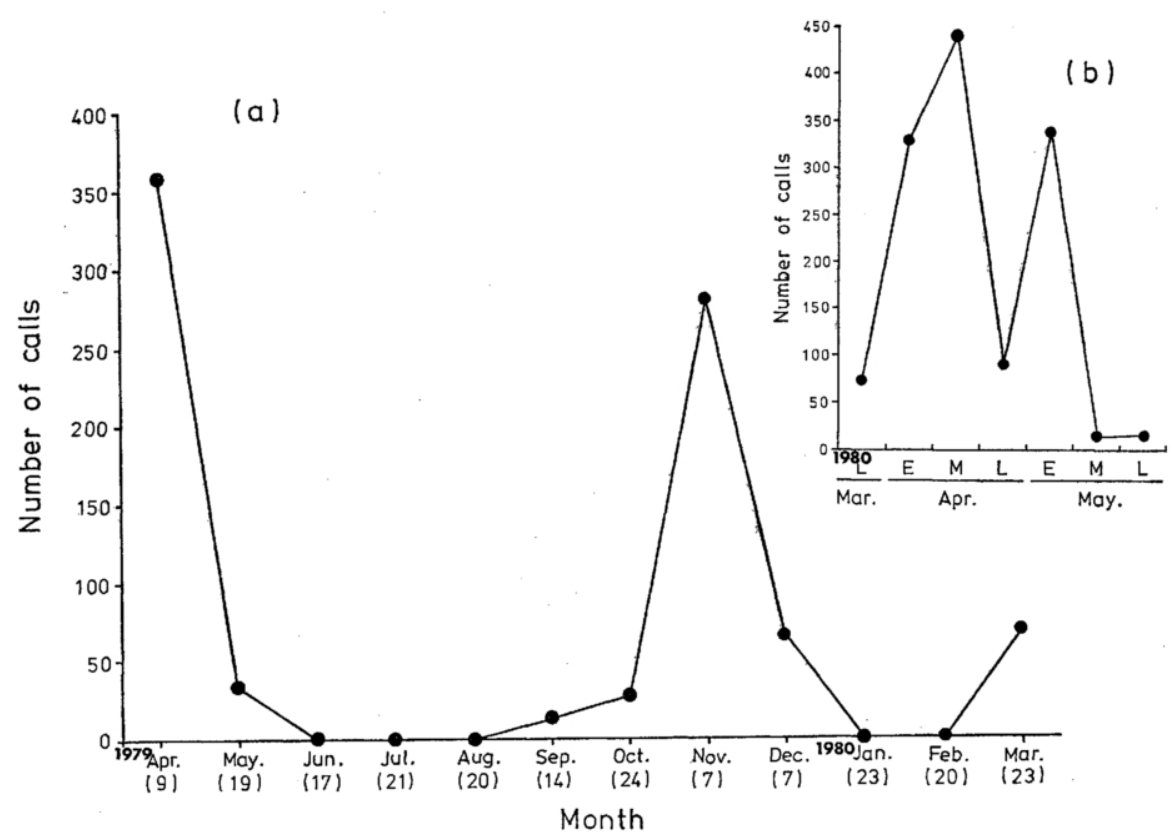

Fig. 3. Seasonal fluctuation of calling frequency in Otus bakkamoena on Miyake-jima, Izu Islands. Numerals in parenthesis indicate the dates when Observations were made.

the call is unknown to us, though similar calls are also heard in the Ural Ow1 Strix uralensis.

Fig. 3 shows the seasonal fluctuation of frequency of the regular call, "koo" or "kwee". Our observations were carried out at one place $(100 \mathrm{~m} \times$ $100 \mathrm{~m}$ ) in Izu Village, Miyake-jima, and recordings were made once a month from April 1979 to March 1980 and once in ten days from April to May 1980. For recordings, calm evenings were chosen, and the number of the calls was counted for two hours after the sunset. The ordinate in Fig. 3 represents the total number of calls recorded during the two-hour observation. Collared Scops Owls have two marked peaks of calling activity in a year (Fig. 3a), one in spring which is associated with the breeding and the other in winter. However, even in the active periods they hardly call on rainy or windy days. The calling duration in spring lasts for about one and a half months, and the peak of calling frequency comes in mid-April to early May (Fig. 3b). The drop in the number of calls in the end of April in Fig. 3b may be due to the low temperature of the particular day when our counts were made.

Acknowledgements. We are indebted to Miss T. ОвА of the University of London for preparing the sonagrams used in this study, and to Dr. L. Adams of the Wild Bird Society of Japan for reading and commenting on our manuscript. 
摘 要

伊豆諸島の三宅島でオオコノハズクの鳴き声を調査した. この鳥が出す声のうち最も普通に聞か れるのは, “クゥー”とか “クウィー”といら声である. この声は雄踓ともに出し, テリトリーの 防衛やつがいの雌雄間のコミュニケーションに用いられているらしい, 4, 5 月と 11 月に鳴きの ピークがある. ほかの声としては, ワォン, ワォンと聞こえるイ邓のような声や，ミュウ，ミャウ と聞こ党るネコのような声がある. 前者は雄が巣に近づくときに発せられる.

\section{LITERATURE CITED}

JAPB (Japanese Association for the Preservation of Birds), 1966. A Field Guide to the Birds of Japan. Tokyo, Japanese Association for the Preservation of Birds. (In Japanese.)

KiYosu, Y., 1965. The Birds of Japan, 2. Tokyo, Kodansha. (In Japanese.)

KobAYASHI, K., 1954. Birds of Japan in Natural Colours. Osaka, Hoikusha. (In Japanese.)

Marshall, J. T., 1978. Systematics of smaller Asian night birds based on voice. Ornith. Monogr., (25): 1-58.

(Received 4 July 1980) 